\title{
The alpha-cypermethrin coated net for protecting Norway spruce wood against bark beetles (Curculionidae, Scolytinae)
}

\author{
Iwona Skrzecz ${ }^{*}$, Wojciech Grodzki ${ }^{1}$, Mieczysław Kosibowicz' ${ }^{1}$, Dorota Tumialis ${ }^{2}$ \\ ${ }^{1}$ Forest Research Institute, Braci Leśnej 3, Sękocin Stary, 05-090 Raszyn, Poland \\ ${ }^{2}$ University of Life Sciences, Faculty of Animals Sciences, Department of Animal Environment Biology, \\ Ciszewskiego 8, 02-786 Warsaw, Poland
}

Received: September 23, 2014

Accepted: April 8, 2015

\begin{abstract}
The study estimated the efficacy of a net coated with alpha-cypermethrin used to protect Norway spruce [Picea abies (L.) H. Karst] wood against bark beetle infestations. The inside of the net was coated with $100 \mathrm{mg} / \mathrm{m}^{2}$ of alpha-cypermethrin. The studies carried out in 2010 and 2011 took place in southern Poland in the Beskid Żywiecki and Beskid Sądecki mountains in P. abies stands threatened by Ips typographus (Linnaeus, 1758). The research material consisted of wood logs taken off of 70-80-year-old P. abies trees. The logs were wrapped in the net in the early spring before spring swarming of bark beetles. The unwrapped logs were considered as the study controls. An evaluation of the treatments was performed after 2 months. The evaluation was based on the counting of bark beetles galleries found after removing the bark from the wrapped and unwrapped logs. There were no insect galleries on the wrapped logs. The net was a barrier, on which bark beetles died. About 10 dead I. typographus beetles were found on $0.01 \mathrm{~m}^{2}$ of the net surface. On the bark from the unwrapped-control logs there were 3,156 galleries/entrance holes of bark beetles, in total, of which 73\% belonged to I. typographus, $13 \%$ to Pityogenes chalcographus (Linnaeus, 1761), and almost $10 \%$ to Xyloterus lineatus (Oliv.). These results indicated the high efficacy of the net coated with alpha-cypermethrin used for the protection of Norway spruce wood against the bark beetles. At the same time, the net was found to have a negative effect on non-target entomofauna, mainly Hylobius spp., Thanasimus formicarius (L.), and Tetropium castaneum (F.). However, the use of a net did not affect other predatory (Carabidae) and parasitic (Ichneumonidae and Tachinidae) entomofauna.
\end{abstract}

Key words: alpha-cypermethrin, net, Picea abies, Scolytids, wood protection

\section{Introduction}

One of the most important problems in the Norway spruce stands is how to protect the processed timber stored in the forest, against the insects that infest the bark, phloem and wood. Among the most important species is the ambrosia beetle Xyloterus lineatus (Olivier, 1795) affecting wood. The European spruce bark beetle Ips typographus (Linnaeus, 1758) being a vector of the blue-stain fungi (Linnakoski et al. 2012), should also be mentioned. The total area of forests in Europe threatened by the European spruce bark beetle is estimated to be about 8 million ha (Grégoire and Evans 2004).

A set of methods exists for controlling the bark beetle populations and damage level. In the case of I. typographus and the accompanying species I. amitinus (Eichhoff, 1871) and Pityogenes chalcographus (Linnaeus, 1761), the most effective method is the identification and fast removal of infested trees before the emergence of a new generation of beetles that develops under the bark (Niemeyer 1997). This approach is usually supported by the use of trap trees and pheromone-baited artificial traps that catch swarming parent beetles. The traps, though, are often considered as not effective enough (e.g. Wes- lien 1992; Grodzki et al. 2008). Conventional chemical insecticides are mostly used to protect stored timber (Wermelinger 2004; Koleva et al. 2012; Lubojacký and Holuša 2014) and systemic chemicals have been reported to protect single susceptible trees (DeGomez et al. 2006; Grosman and Upton 2006; Billings 2011). Emamectin benzoate and fipronil show substantial promise for preventing bark beetle attacks (Grosman and Upton 2006). At present in the USA, only the insecticides containing bifenthrin or permethrin are available for bark beetle prevention, and then only to protect trees in urban settings, but not in forests (Billings 2011).

In Central Europe the use of insecticides, including alpha-cypermethrin, in the protection of Norway spruce and Scots pine wood, is a method which has been used for over 25 years (Zahradník et al. 1996; Novotny and Zúbrik 2000). This substance has been used most often as an active ingredient of the insecticide Fastac 100 EC (formerly $10 \mathrm{EC}$ ) at $10 \%$ in 1 liter of formulation. It is recommended that this product be applied as a wood spray in a concentration of $0.3-0.5 \%$ before bark beetle attack.

According to the formal regulations of the Polish State Forests, the application of insecticides is very lim- 
ited; in the mountains it is not allowed at all due to water protection (Instrukcja ochrony lasu 2012). On the other hand, due to ecological limitations as well as expensive and lengthy procedures relating to the registration, the number of insecticides registered for wood protection has been decreasing each year. Insecticide use is also not recommended by certification authorities such as Forest Stewardship Council (FSC).

The control of bark beetles and the protection of stored timber in spruce stands is complicated and timeconsuming, especially in outbreak conditions. In the mountains, it is much more difficult to apply control methods successfully and correctly. The difficulty is due to the shorter vegetation season, protection of watersheds, diversified terrain configuration, and related technical problems (Szabla 2013). For these reasons, there is a need for new methods which will enhance control effectiveness and reduce the work needed. One such method focused on the environmentally safe application of the insecticides, is described in this paper. The aim of this study, conducted from 2010 to 2011, was to estimate the efficacy of a net filled up with the alphacypermethrin used for wrapping Norway spruce wood to protect the timber from the bark beetles. Since $I$. typographus commonly occurs in spruce forests and infests stored fresh timber in the forest, this species was used us the main example for demonstrating the effectiveness of the tested method.

\section{Materials and Methods}

Study area

The experiments were located in the area administrated by the regional directorates of State Forests in Katowice and Kraków, in the Forest Districts Jeleśnia (coordinates: $\left.49^{\circ} 32^{\prime} \mathrm{N}, 1^{\circ} 17^{\prime} \mathrm{E}\right)$ and Krościenko $\left(49^{\circ} 26^{\prime} \mathrm{N}, 20^{\circ} 33^{\prime} \mathrm{E}\right)$ located in Beskid Żywiecki and Beskid Sądecki in the Western Carpathians. The climate in these areas is similar and characterised by a typical zonation associated with an increased altitude above sea level from about 500 to $1557 / 1266 \mathrm{~m}$, respectively. The annual precipitation is approximately $800-1,100 \mathrm{~mm}$, and is a function of elevation (being lowest at $500 \mathrm{~m}$ a.s.l., and highest at above $1200 \mathrm{~m}$ a.s.l.). The mean annual temperature is approximately $4-7^{\circ} \mathrm{C}$, and is negatively correlated with elevation (Brzeźniak and Czemerda 2000).

The forests on the above-mentioned areas are classified as water-protective forests where the dominant species is the Norway spruce. The study was carried out in the $P$. abies stands threatened by bark beetles (Scolytinae), especially: the spruce bark beetle I. typographus, and accompanying, economically less important bark beetle species.

In both years, the experiments were located in spruce (P. abies) stands which were 70-90 years old. The stands were at three altitudes: 500, 800, and 1,100 m a.s.l.

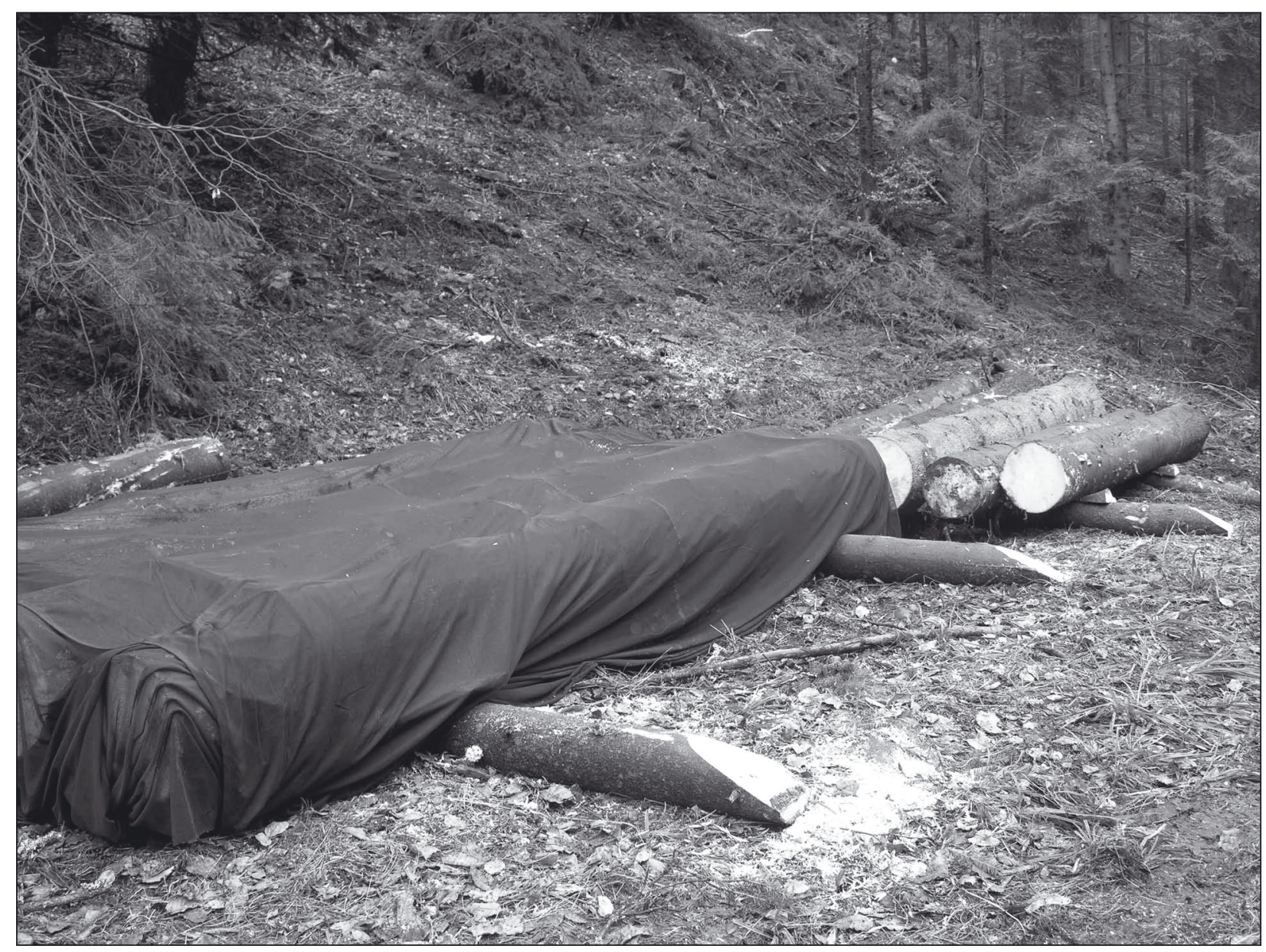

Fig. 1. The logs wrapped in Storanet ${ }^{\circledR}$ and control (not wrapped) logs 


\section{Wood material and treatment}

At the beginning of April 2010 and 2011 the Norway spruces (70-80 year old) were felled. They were made into logs $4 \mathrm{~m}$ in length, and $40-55 \mathrm{~cm}$ in diameter, with an average of $47.3 \pm 5.8 \mathrm{~cm}$. The bark area of each log was between 2.1 and $2.5 \mathrm{~m}^{2}$, with an average of $2.3 \pm 0.21 \mathrm{~m}^{2}$. The logs were not initially infested by insects. Then, each year, at each of the 3 altitudes a.s.l., a set of 2 experimental piles was exposed: 1 pile of wood consisted of 5 logs (5 replications) wrapped in the net, and 1 pile of wood consisted of 5 logs not wrapped which was the control of the experiment. During the 2 year study, 60 logs of Norway spruce wood stacked in 12 piles were observed ( 2 piles $\times 3$ altitudes $\times 2$ years) (Fig. 1 ).

The treatments were started at the beginning of May of each year, before bark beetle swarming. For protecting the wood a product called Storanet ${ }^{\circledR}$ (producer BASF SE) was used, which is a polyester net $\left(24 \mathrm{mesh} / \mathrm{cm}^{2}\right)$ and the inside of the net contained $100 \mathrm{mg} / \mathrm{m}^{2}$ alpha-cypermethrin. Additionally, a polymeric binder was used within the net. The binder prevented leaching of the insecticide by water and ensured insecticidal activity for 6 months. Each pile (both protected and unprotected) was baited with the synthetic pheromone Pheroprax Ampoule ${ }^{\circledR}$ (BASF) to attract the I. typographus beetles.

The experiments were located in protective mountain forests. In Poland, the spraying of insecticide is not allowed in such protective forests. Due to this regulation, standard insecticide was not used as a comparison.

\section{Treatment evaluation}

An evaluation of the treatment was performed after 2 months - in early July of each year. Before removing the Storanet ${ }^{\circledR}$, all insects found on the net's surface were collected to estimate the impact of treatment on non-target entomofauna. Next the Storanet ${ }^{\circledR}$ was removed and a $1 \mathrm{~m}^{2}$ area on each treated and untreated log was debarked (2 areas of $0.5 \mathrm{~m}^{2} / \log$ on the $\log$ ends). Then, the bark beetle galleries and entrance holes were counted. The one-way ANOVA was used for the testing the differences between variants. The Tukey HSD (Honestly Significant Difference) test was used to distinguish homogeneous groups of galleries.

\section{Results and Discussion}

\section{Treatment effectiveness}

Although many studies are aimed at protecting the forest against insects, this problem is still relevant, especially in North and South America, Asia, and Europe. Early methods for killing bark beetles in America were pointed at the rapid utilisation of infested trees: burning or exposing infested logs to a solar heating source and then immersing them in water (Billings 2011). In European forests the measures most commonly applied for this purpose are clearing windthrows, felling of infested trees, and the use of trapping devices (Wermelinger 2004). The search for more efficient methods to protect the trees against bark beetles led to the use of chemical sprays as well as injecting the insecticides into the stems of recently infested trees. Conventional chemical insecticides are mostly used to protect stored timber (Wermelinger 2004). The systemic chemicals have been reported to protect individual, susceptible trees (Bombosch and Dedek 1994; DeGomez et al. 2006).

The tested product Storanet ${ }^{\circledR}$ coated with alpha-cypermethrin allows precise application of insecticide, and due to a slow-release system, leads to the limitation of treatment replications. Furthermore, the active agent is not rinsed out from the net by water, which recommends the use of this net in mountain conditions.

The logs were wrapped in Storanet ${ }^{\circledR}$. On the Storanet ${ }^{\circledR}$ surface many $I$. typographus beetles died due to contact with the net - approximately 10 specimens $/ 0.01 \mathrm{~m}^{2}$ were found (Table 1). There were no differences between the numbers of beetles found on those nets located at different altitudes $(\mathrm{df}=49, \mathrm{~F}=0.7807, \mathrm{p}=0.4637)$. It can be assumed, that the mortality of the beetles was actually higher because most of them flew away after contact with the net and died at a certain distance from the protected wood. Thus, due to the dispersion of contaminated insects (both active and passive by wind or water), a precise evaluation of their total mortality was not feasible. The net was not perforated by the insects. After the debarking of logs wrapped in the Storanet ${ }^{\circledR}$, no galleries of bark beetles were found in the cambium and wood.

Table 1. The number of Ips typographus beetles found on Storanet ${ }^{\circledR}$ with alpha-cypermethrin

\begin{tabular}{cc}
\hline Altitude a.s.l. $[\mathrm{m}]$ & $\begin{array}{c}\text { Average number of beetles } \\
\text { on } 0.01 \mathrm{~m}^{2} \text { of Storanet }{ }^{\circledR} \pm S D\end{array}$ \\
\hline 500 & $8.8 \pm 2.3$ \\
800 & $10.4 \pm 3.1$ \\
1,100 & $9.7 \pm 2.6$ \\
\hline
\end{tabular}

Different results were obtained on the control logs: there were 3,156 galleries/entrance holes all together (an average of $59 \pm 28.7$ galleries $/ \mathrm{m}^{2}$ ) of which $2,340(74 \%)$ belonged to I. typographus, 411 (13.1\%) to P. chalcographus, $310(9.8 \%)$ to X. lineatus, 51 (1.6\%) to I. amitinus, $45(1.3 \%)$ to Hylurgops palliatus (Gyllenhall, 1813), and $5(0.2 \%)$ to Dryocoetes autographus (Ratzeburg, 1837).

There were no differences found in the total number of bark beetle galleries at different altitudes ( $\mathrm{df}=49$, $\mathrm{F}=0.1483, \mathrm{p}=0.8626$ ) (Table 2). Also the numbers of the I. typographus galleries were similar at different altitudes $(\mathrm{df}=49, \mathrm{~F}=2.0017, \mathrm{p}=0.1460)$ (Table 2). On the other hand, the numbers of galleries established by $P$. chalcographus varied according to the altitude $(\mathrm{df}=49$, $\mathrm{F}=89.48946, \mathrm{p}=0.0007)$ and were the highest at $800 \mathrm{~m}$ a.s.l., twice lower at $500 \mathrm{~m}$ a.s.l., and the lowest at $1100 \mathrm{~m}$ a.s.l. This variability, however, seems to be related to local microclimatic conditions (humidity) rather than to the altitude (Grodzki and Plata 2008). Xyloterus lineatus entrance holes were only found in similar numbers $(\mathrm{df}=49, \mathrm{~F}=8.3985, \mathrm{p}=0.8941)$ on logs located at the lower 
Table 2. The numbers of bark beetle galleries on experimental Picea abies logs

\begin{tabular}{|c|c|c|c|c|c|}
\hline \multirow{2}{*}{$\begin{array}{l}\text { Altitude } \\
\text { a.s.l. [m] }\end{array}$} & \multirow[b]{2}{*}{ Variant } & \multicolumn{4}{|c|}{ Average number of bark beetle galleries on $1 \mathrm{~m}^{2}$ of debarked area $\pm \mathrm{SD}$} \\
\hline & & Ips typographus & Pityogenes chalcographus & Xyloterus lineatus & $\begin{array}{c}\text { total bark beetle } \\
\text { galleries }\end{array}$ \\
\hline \multirow{2}{*}{500} & Storanet ${ }^{\circledR}$ & 0 & 0 & 0 & 0 \\
\hline & unprotected & $52.1 \pm 25.4$ & $6.8 \pm 3.3 a^{*}$ & $6.4 \pm 4.1$ & $57.4 \pm 21.6$ \\
\hline \multirow{2}{*}{800} & Storanet ${ }^{\circledR}$ & 0 & 0 & 0 & 0 \\
\hline & unprotected & $35.8 \pm 23.2$ & $14.6 \pm 13.4 \mathrm{~b}$ & $7.2 \pm 3.8$ & $57.0 \pm 17.2$ \\
\hline \multirow{2}{*}{1,100} & Storanet ${ }^{\circledR}$ & 0 & 0 & 0 & 0 \\
\hline & unprotected & $43.7 \pm 23.6$ & $3.4 \pm 0.8 \mathrm{c}$ & 0 & $61.5 \pm 38.7$ \\
\hline
\end{tabular}

*different letters show statistical differences at $\mathrm{p} \leq 0.05$

Table 3. Non-target insect species found on Storanet ${ }^{\circledR}$ with alpha-cypermethrin

\begin{tabular}{|c|c|c|c|}
\hline Order & Family & Genus or species & Abundance* \\
\hline \multirow[t]{20}{*}{ Coleoptera } & Cerambycidae & Molorchus minor (Linnaeus, 1758) & + \\
\hline & & Oxymirus cursor (Linnaeus, 1758) & + \\
\hline & & Tetropium castaneum (Linnaeus, 1758) & ++ \\
\hline & & Rhagium inquisitor (Linnaeus, 1758) & + \\
\hline & & Pidonia lurida (Fabricius, 1792) & + \\
\hline & Carabidae & Carabus linnaei (Panzer, 1810) & + \\
\hline & & Carabus sylvestris (Panzer, 1793) & + \\
\hline & & Pterostichus oblongopunctatus (Fabricius, 1787) & + \\
\hline & & Pterostichus (Bonelli, 1810) & + \\
\hline & Lycidae & Dictyoptera aurora (Herbst, 1784) & + \\
\hline & Cantharidae & Cantharis rustica (Fallén, 1807) & + \\
\hline & Cleridae & Thanasimus formicarius (Linnaeus, 1758) & ++ \\
\hline & Elateridae & Athous subfuscus (O.F. Müller, 1764) & ++ \\
\hline & & Melanotus (Eschscholtz, 1829) & + \\
\hline & & Ampedus pomorum (Herbst, 1784) & + \\
\hline & Curculionidae & Otiorhynchus tenebricosus (Herbst, 1784) & ++ \\
\hline & & Hylobius pinastri (Gyllenhal, 1813) & +++ \\
\hline & & Hylobius abietis (Linnaeus, 1758) & +++ \\
\hline & & Polydrusus (Germar, 1813) & + \\
\hline & Silphidae & Silpha carinata (Herbst, 1783) & + \\
\hline Blattodea & Blattellidae & Ectobius sylvestris (Poda, 1761) & + \\
\hline Hemiptera & Pentatomidae & Palomena prasina (Linnaeus, 1761) & + \\
\hline \multirow[t]{2}{*}{ Hymenoptera } & Formicidae & Camponotus herculeanus (Linnaeus, 1758 ) & + \\
\hline & Apidae & Bombus (Latreille, 1802) & + \\
\hline
\end{tabular}

*abundance of insects on $0.5 \mathrm{~m}^{2}$ of the surface net: +++ - up to 5 specimens, ++ - up to 3 specimens, +- occasionally

(500 and $800 \mathrm{~m}$ a.s.1.) altitudes, in more humid storage sites, which are preferred by this species. The galleries established by other species were found only incidentally.

The use of Storanet ${ }^{\circledR}$ was also tested in neighbouring countries - in the Czech Republic and Slovakia. No information about the results from Slovakia has been published. The results from the Czech Republic showed the same, high protective effect of the net as obtained in Poland, and the impact on non-target insects was comparable as with the use of classic insecticides on sprayed trap logs (Geráková 2011). It should be pointed out, that Storane ${ }^{\circledR}$ is the method of protection for already processed, fresh logs against the infestation by bark- and wood-boring insects (mainly $X$. lineatus, damaging wood quality) and the emergence of new beetles from infested logs. Sprayed logs acting as traps for killing insects, on the other hand, are focused on protecting standing trees against insect attack. From this point of view, any comparisons of those methods in terms of forest protection is not available. In the experiments, no phytotoxic effect of the Storane ${ }^{\circledR}$ on the Norway spruce wood was observed.

\section{Effect of Storanet ${ }^{\circledR}$ on non-target organisms}

Observations of insects found on the Storanet ${ }^{\circledR}$ showed the presence of 23 species and 4 genera belonging to the following groups (Table 3 ):

- insects trophically associated with P. abies: Coleoptera: Curculionidae (mainly Scolytinae), and Cerambycidae;

- predators feeding on insects associated with P. abies: Coleoptera: Cleridae, Carabidae, and Elateridae; 
- accidentally killed insects: Hymenoptera: Formicidae, Apidae; Blattodea: Blattellidae; Hemiptera: Pentatomidae; Coleoptera: Carabidae, Silphidae.

All insects found on the Storanet ${ }^{\circledR}$ surface were killed by the contact with insecticide. The most abundant of the insects killed belonged to the genus Hylobius Germar, 1817 - up to 5 beetles $/ 0.5 \mathrm{~m}^{2}$ of the Storanet ${ }^{\circledR}$. They were likely attracted by volatiles, mainly $\alpha$-pinene and ethanol, released from the resin of cut trees (Tilles et al. 1986; Nordlander 1987).

The synthetic pheromone Pheroprax Ampoule ${ }^{\circledR}$, as well as natural pheromones released by I. typographus beetles, attracted Thanasimus formicarius (Linnaeus, 1758) (up to 3 beetles $/ 0.5 \mathrm{~m}^{2}$ of the net surface). The Thanasimus formicarius beetles are one of the most common predators of spruce bark beetles in Europe (Kenis et al. 2004). Bakke and Kvamme (1978) observed that T. formicarius beetles respond to some compounds of the aggregation pheromones secreted by I. typographus. Similar results were obtained by Lubojacký and Holuša (2014) who studied the impact of the insecticide Vaztak 10 SC (an analog of Fastac 10 EC in Poland) which had been applied as a wood spray and which had caught non-target arthropods in Norway spruce stands. These authors confirmed that such treatments led to the death of the predators: T. formicarius and T. femoralis (Zetterstedt, 1828) which had been sitting on P. abies wood treated with alpha-cypermethrin based insecticides. However, the pheromone traps, commonly used in forest protection, also cause unwanted mortality of non-target insects including the predators T. formicarius and T. femoralis (Babuder et al. 1996; Grodzki 2007), but this unwanted mortality is not as high as in case of the use of trap logs sprayed with insecticide (Koleva et al. 2012; Lubojacký and Holuša 2014). Tetropium castaneum (Linnaeus, 1758 ) beetles were also often found on the net surface: $1-2$ beetles $/ 0.5 \mathrm{~m}^{2}$ of the Storanet ${ }^{\circledR}$. The T. castaneum, a pest of $P$. abies, prefers freshly felled trees and trees weakened by the biotic (insects, fungi) or abiotic (drought, air pollution, etc.) factors (Evans et al. 2004). However, in the case of a high population level, healthy trees can also be attacked. Other insects were found sporadically within the two years of the study. At the same time, no negative or positive effects on parasitic Ichneumonidae and Tachinidae as well as Lepidoptera, were observed.

In conclusion, the present study shows that use of a net containing alpha-cypermethrin, resulted in complete protection of $P$. abies trees and timber against bark and ambrosia beetle infestations. There were no insect galleries on logs which had been wrapped in the net, while numerous galleries were found on unprotected logs. The Storanet ${ }^{\circledR}$ can be recommended for use in forestry practice to protect timber, and as a barrier for beetles emerging from infested logs. On the other hand, the product is characterised by low selectivity, because besides the bark beetles it affects their predators that are natural regulators of pest populations.

\section{Acknowledgements}

The authors thank the BASF Company for providing the net, and the Foresty Districts in Jeleśnia and Krościenko for their technical support in the organising of the studies.

\section{References}

Babuder G., Pohleven F., Brelih S. 1996. Selectivity of synthetic aggregation pheromones Linoprax and Pheroprax in the control of the bark beetles (Coleoptera, Scolytidae) in a timber storage yard. Journal of Applied Entomology 120: 131-136.

Bakke A., Kvamme T. 1978. Kairomone response by the predators Thanasimus formicarius and Thanasimus rufipes to the synthetic pheromone of Ips typographus. Norwegian Journal of Entomology 25 (1): 41-43.

Billings R.F. 2011. Use of chemicals for prevention and control of Southern Pine Beetle infestations. p. 367-379. In: "Southern Pine Beetle II. General Technical Reports SRS-140" (R.N. Coulson, K.D. Klepzig, eds.). Department of Agricultural Forest Service, Southern Research Station, USA, 285 pp.

Bombosch S., Dedek W. 1994. Integrierter Pflanzenschutz gegen Ips typographus (L.) - Kombination von pheromonen und dem systemischen insektizid methamidophos (IPIDEX). [Integrated plant protection against Ips typographus (L.) Combination of pheromones and the systemic insecticide methamidophos (IPIDEX)]. Zeitschrift für Pflanzenkrankheiten and Pflanzenschutz 101: 508-518.

Brzeźniak E., Czemerda A. 2000. Klimat. [Climate]. p. 37-46. In: „Przyroda Popradzkiego Parku Krajobrazowego" (J. Staszkiewicz, ed.). Popradzki Park Krajobrazowy, Stary Sącz, Poland, 324 pp. (in Polish)

Evans H.F., Moraal L.G., Pajares J.A. 2004. Biology, ecology and economic importance of Buprestidae and Cerambycidae. p. 447-474. In: "Bark and Wood Boring Insects in Living Trees in Europe, a Synthesis" (F. Lieutier, K.R. Day, A. Battisti, J.-C. Grégoire, H.F. Evans, eds.). Kluwer Academic Publishers, 570 pp.

DeGomez T.E., Hayes C.J., Anhold J.A., McMilin J.D., Clancy K.M., Bosu P.P. 2006. Evaluation of insecticides for protecting southwestern ponderosa pines from attack by engraver beetles (Coleoptera: Curculionidae: Scolytinae). Journal of Economic Entomology 99 (2): 393-400.

Geráková M. 2011. Nová technologie v ochraně lesa proti lýkožroutu smrkovému. [New technology in forest protection against spruce bark beetle]. Lesnická Práce 90 (7): 24-25. (in Czech)

Grégoire J.C., Evans H.F. 2004. Damage and control of BAWBILT organisms, an overview. p. 19-38. In: "Bark and Wood Boring Insects in Living Trees in Europe, a Synthesis" (F. Lieutier, K.R. Day, A. Battisti, J.-C. Grégoire, H.F. Evans, eds.). Kluwer Academic Publishers, 570 pp.

Grodzki W. 2007. The use of pheromone traps for the monitoring of Ips typographus (L.) populations in selected national parks in the Carpathians. Prace Instytutu Badawczego Leśnictwa, Rozprawy i Monografie 8: 1-127.

Grodzki W., Kosibowicz M., Mączka T. 2008. Skuteczność wystawiania pułapek feromonowych na kornika drukarza Ips typographus (L.) w sąsiedztwie wiatrowałów i wiatrołomów. [The effectiveness of putting pheromone traps for bark beetle Ips typographus (L.) in the vicinity of windfalle and windblow]. Leśne Prace Badawcze 69 (4): 365-370. (in Polish)

Grodzki W., Plata J. 2008. Składowany surowiec świerkowy jako materiał lęgowy rytownika pospolitego Pityogenes chalcographus (L.) (Col., Curculionidae, Scolytinae). [Stored spruce timber as the breeding material for Pityogenes chal- 
cographus (L.) (Col., Curculionidae, Scolytinae)]. Leśne Prace Badawcze 69 (3): 197-201. (in Polish)

Grosman D.M., Upton W.W. 2006. Efficacy of systemic insecticides for protection of loblolly pine against southern pine engraver beetles (Coleoptera: Curculionidae: Scolytinae) and wood borers (Coleoptera: Cerambycidae). Journal of Economic Entomology 99 (1): 94-101.

Instrukcja ochrony lasu. [Forest Protection Instruction]. 2012. Centrum Informacyjne Lasów Państwowych, Warszawa, 276 pp. (in Polish)

Kenis M., Wermelinger B., Grégoire J-C. 2004. Research on parasitoids and predators of Scolytidae. p. 237-290. In: "Bark and Wood Boring Insects in Living Trees in Europe, a Synthesis" (F. Lieutier, K.R. Day, A. Battisti, J.-C. Grégoire, H.F. Evans, eds.). Kluwer Academic Publishers, 570 pp.

Koleva P., Kolev N., Schopf A., Wegensteiner R. 2012. Untersuchungen zur Effizienz von insektizidbehandelten Fanghölzern gegen den Buchdrucker Ips typographus (Coleoptera, Curculionidae). [Investigations of the efficacy of insecticide-treated wood against the spruce bark beetle Ips typographus (Coleoptera, Curculionidae)]. Forstschutz Aktuell 54: 16-21.

Linnakoski R., de Beer Z.W., Niemelä P., Wingfield M.J. 2012. Associations of conifer-infesting bark beetles and fungi in Fennoscandia. Insects 3 (1): 200-227.

Lubojacký J., Holuša J. 2014. Effect of insecticide-treated trap logs and lure traps for Ips typographus (Coleoptera: Curculionidae) management on nontarget arthropods catching in Norway spruce stands. Journal of Forest Science 60 (1): 6-11.

Niemeyer H. 1997. Integrated bark beetle control: experiences and problems in Northern Germany. USDA Forest Service General Technical Report NE-236: 80-86.
Nordlander G. 1987. A method for trapping Hylobius abietis (L.) with a standardized bait and its potential for forecasting seedling damage. Scandinavian Journal of Forest Research 2 (1-4): 199-213.

Novotny J., Zúbrik M. (eds.). 2000. Biotickí škodcovia lesov slovenska. [Biotic Pests of Slovakia Forests]. Lesnickasekcia Ministerstva pôdohospodárstva SR, 206 pp. (in Slovak)

Szabla K. 2013. Praktyczna realizacja strategii ograniczania liczebności kornika drukarza na przykładzie świerczyn Beskidu Śląskiego i Żywieckiego w latach 2007-2010. [The practical implementation of the strategy for limiting the number of spruce bark beetle on the example of spruce forests in Silesian and Żywiecki Beskid in 2007-2010.] p. 161-178. In: „Kornik drukarz Ips typographus (L.) i jego rola w ekosystemach leśnych". [“Spruce bark beetle Ips typographus (L.) and its role in forest ecosystems"]. (W. Grodzki, ed.). Centrum Informacyjne Lasów Państwowych, Warszawa, Poland, 213 pp. (in Polish)

Tilles D.A., Nordlander G., Nordenhem H., Eidmann H.H., Wassgren A.-B., Bergström G. 1986. Increased release of host volatiles from feeding scars: A major cause of field aggregation in the pine weevil Hylobius abietis (Coleoptera: Curculionidae). Environmental Entomology 15: 1050-1054.

Wermelinger B. 2004. Ecology and management of the spruce bark beetle Ips typographus - A review of recent research. Forest Ecology and Management 202: 67-82.

Weslien J. 1992. Effects of mass trapping on Ips typographus (L.) populations. Journal of Applied Entomology 114 (1-5): 228-232.

Zahradník P., Švestka M., Novák Knížek M. 1996. Podkorní škůdci. [Bark pests]. p. 118-144. In: "Praktické metody v ochraně lesa" (M. Švestka, R. Hochmut, V. Jančařík, eds.) Nakladelství Silva Regina, Praha, Czech Republic, 186 pp. (in Czech) 